\title{
An integrated approach to understand apicomplexan metabolism from their genomes
}

\author{
Achchuthan Shanmugasundram ${ }^{1,2^{*}}$, Faviel F Gonzalez-Galarza', Jonathan M Wastling², Olga Vasieva', \\ Andrew R Jones ${ }^{1}$ \\ From Ninth International Society for Computational Biology (ISCB) Student Council Symposium 2013 \\ Berlin, Germany. 19 July 2013
}

\section{Background}

The Apicomplexa is a large phylum of intracellular parasites that show great diversity and adaptability in the various ecological niches they occupy. They are the causative agents of human and animal infections including malaria, toxoplasmosis and theileriosis, which have a huge economic and social impact. A number of apicomplexan genomes have been sequenced and are publicly available. However, the prediction of gene models and annotation of gene functions remains challenging.

\section{Methods}

We have utilised an approach called 'metabolic reconstruction', in which genes are systematically assigned to functions within pathways/networks [1-4]. Functional annotation and metabolic reconstruction was carried out using a semi-automatic approach, integrating genomic information with biochemical evidence from the literature. The functions were automatically assigned using a sequence similarity-based approach and protein motif information. Experimental evidence was also

Table 1 A survey of the data available for the different apicomplexan genomes in LAMP. The analysis is updated from the survey table published in the previous publication [5]

\begin{tabular}{|c|c|c|c|c|c|c|c|}
\hline Organism & $\begin{array}{l}\text { No of metabolic } \\
\text { pathways }\end{array}$ & $\begin{array}{l}\text { No of unique } \\
\text { enzymes }^{a}\end{array}$ & $\begin{array}{l}\text { No of missing } \\
\text { enzymes }\end{array}$ & $\begin{array}{l}\text { No of } \\
\text { reactions }\end{array}$ & $\begin{array}{l}\text { Total no of } \\
\text { metabolites }\end{array}$ & $\begin{array}{l}\text { No of metabolites } \\
\text { from host }\end{array}$ & $\begin{array}{l}\text { No of end } \\
\text { metabolites to host } \\
\text { or of unknown fate }\end{array}$ \\
\hline T. gondii & 51 & 419 & 17 & 509 & 500 & 41 & 23 \\
\hline N. caninum & 51 & 412 & 23 & 509 & 500 & 41 & 23 \\
\hline C. muris & 31 & 224 & 15 & 255 & 281 & 32 & 7 \\
\hline C. parvum & 28 & 207 & 10 & 231 & 261 & 31 & 8 \\
\hline C. hominis & 28 & 200 & 17 & 230 & 261 & 31 & 8 \\
\hline T. parva & 32 & 213 & 17 & 234 & 258 & 26 & 9 \\
\hline T. annulata & 32 & 214 & 16 & 235 & 258 & 26 & 9 \\
\hline B. bovis & 32 & 216 & 11 & 233 & 256 & 26 & 9 \\
\hline
\end{tabular}

${ }^{a}$ Unique Enzymes represent total unique enzyme activities (enzymes with full, partial and no EC numbers) annotated to be present in the pathways for an organism. ${ }^{b}$ Missing enzymes represent the enzymes need to be present to complete the metabolic pathways. They may either be missing in the gene model predictions or may be absent in the organism.

c Total number of biochemical reactions annotated to metabolic pathways from KEGG REACTION database.

d Total number of metabolites annotated to metabolic pathways from KEGG COMPOUND and KEGG GLYCAN databases.

e Number of precursor metabolites in the metabolic pathways that are annotated to be obtained from host. This number does not include any other metabolites that are obtained from host and not part of any of the annotated pathways in LAMP.

${ }^{f}$ Number of end metabolites in the metabolic pathways that does not end up in a downstream pathway. These can either be metabolites that end up in host or the fate pathways are unknown.

\footnotetext{
* Correspondence: ashanmu@liv.ac.uk

${ }^{1}$ Institute of Integrative Biology, University of Liverpool, Biosciences Building, Crown Street, Liverpool L69 7ZB, UK
} 
accommodated in the confirmation of functions and the grouping of genes into metabolic pathways.

\section{Results}

A web database named Library of Apicomplexan Metabolic Pathways (LAMP, http://www.llamp.net) [5] was developed to deposit the reconstructed metabolic pathways of Toxoplasma gondii, Neospora caninum, Cryptosporidium and Theileria species and Babesia bovis. Each metabolic pathway page contains an interactive metabolic pathway map, gene annotations hyperlinked to external resources and detailed information about the metabolic capabilities. This analysis led to the identification of missing enzymes that must be present to complete the metabolic pathway and orphan genes (incorrect enzyme annotations or enzymes that are involved in salvage of metabolites) that are isolated in pathways that are otherwise absent. The compilation and annotation of metabolic pathways and the comparative analysis of the overall metabolic capabilities of apicomplexan species enabled identification of differences in their ability to synthesise or depend on hosts for several metabolites (Table 1, Additional file 1).

\section{Conclusions}

The carefully annotated metabolic pathways and the comparative analysis of metabolism for eight apicomplexan species are publicly available for the research community in the LAMP database (http://www.llamp. net). This has improved the functional annotation immensely and led to identification of putative drug targets. The hyperlinks for LAMP metabolic pathway annotations are available from the respective gene pages of the T. gondii primary database, ToxoDB (release 9) [6], enabling a wider reach for LAMP.

\section{Additional material}

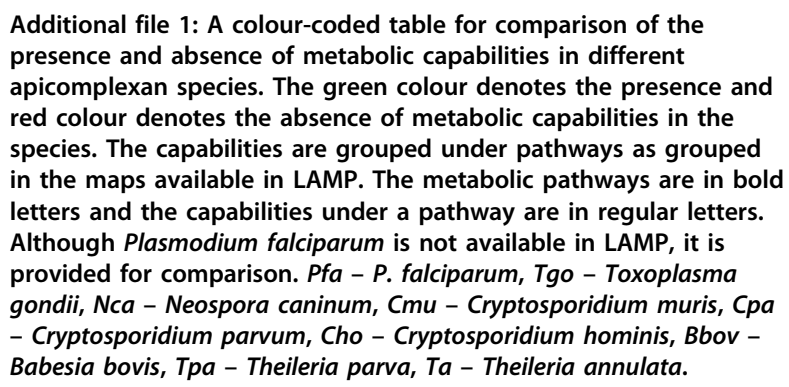

\section{Acknowledgements}

LAMP web database was already published in the database issue of Nucleic acids research (January 2013). LAMP is indirectly funded through several grants from Biotechnology and Biological Sciences Research Council. Travel expenses of AS to the ISCB Student Council Symposium was funded from the BBSRC DTG studentship awarded to the University of Liverpool.

\section{Authors' details}

'Institute of Integrative Biology, University of Liverpool, Biosciences Building, Crown Street, Liverpool L69 7ZB, UK. ${ }^{2}$ Institute of Infection and Global Health, University of Liverpool, Liverpool Science Park Innovation Centre 2, 146 Brownlow Hill, Liverpool L3 5RF, UK.

Published: 11 February 2014

\section{References}

1. Karp PD, Paley S: Integrated access to metabolic and genomic data. J Comput Biol 1996, 3:191-212.

2. Karp PD, Krummenacker M, Paley S, Wagg J: Integrated pathway-genome databases and their role in drug discovery. Trends Biotechnol 1999, 17:275-281.

3. Keseler IM, Collado-Vides J, Santos-Zavaleta A, Peralta-Gil M, Gama-Castro S, Muñiz-Rascado L, Bonavides-Martinez C, Paley S, Krummenacker M, Altman T, et al: EcoCyc: a comprehensive database of Escherichia coli biology. Nucleic Acids Res 2011, 39:D583-D590.

4. Pinney JW, Papp B, Hyland C, Wambua L, Westhead DR, McConkey GA: Metabolic reconstruction and analysis for parasite genomes. Trends Parasitol 2007, 23:548-554.

5. Shanmugasundram A, Gonzalez-Galarza FF, Wastling JM, Vasieva O, Jones AR: Library of Apicomplexan Metabolic Pathways: a manually curated database for metabolic pathways of apicomplexan parasites. Nucleic Acids Research 2013, 41:D706-D713.

6. Gajiia B, Bahl A, Brestelli J, Dommer J, Fischer S, Gao X, Heiges M, lodice J, Kissinger JC, Mackey AJ, et al: ToxoDB: an integrated Toxoplasma gondii database resource. Nucleic Acids Res 2008, 36:D553-D556.

doi:10.1186/1471-2105-15-S3-A3

Cite this article as: Shanmugasundram et al: An integrated approach to understand apicomplexan metabolism from their genomes. BMC Bioinformatics 2014 15(Suppl 3):A3.

\section{Submit your next manuscript to BioMed Central} and take full advantage of:

\footnotetext{
- Convenient online submission

- Thorough peer review

- No space constraints or color figure charges

- Immediate publication on acceptance

- Inclusion in PubMed, CAS, Scopus and Google Scholar

- Research which is freely available for redistribution
} 